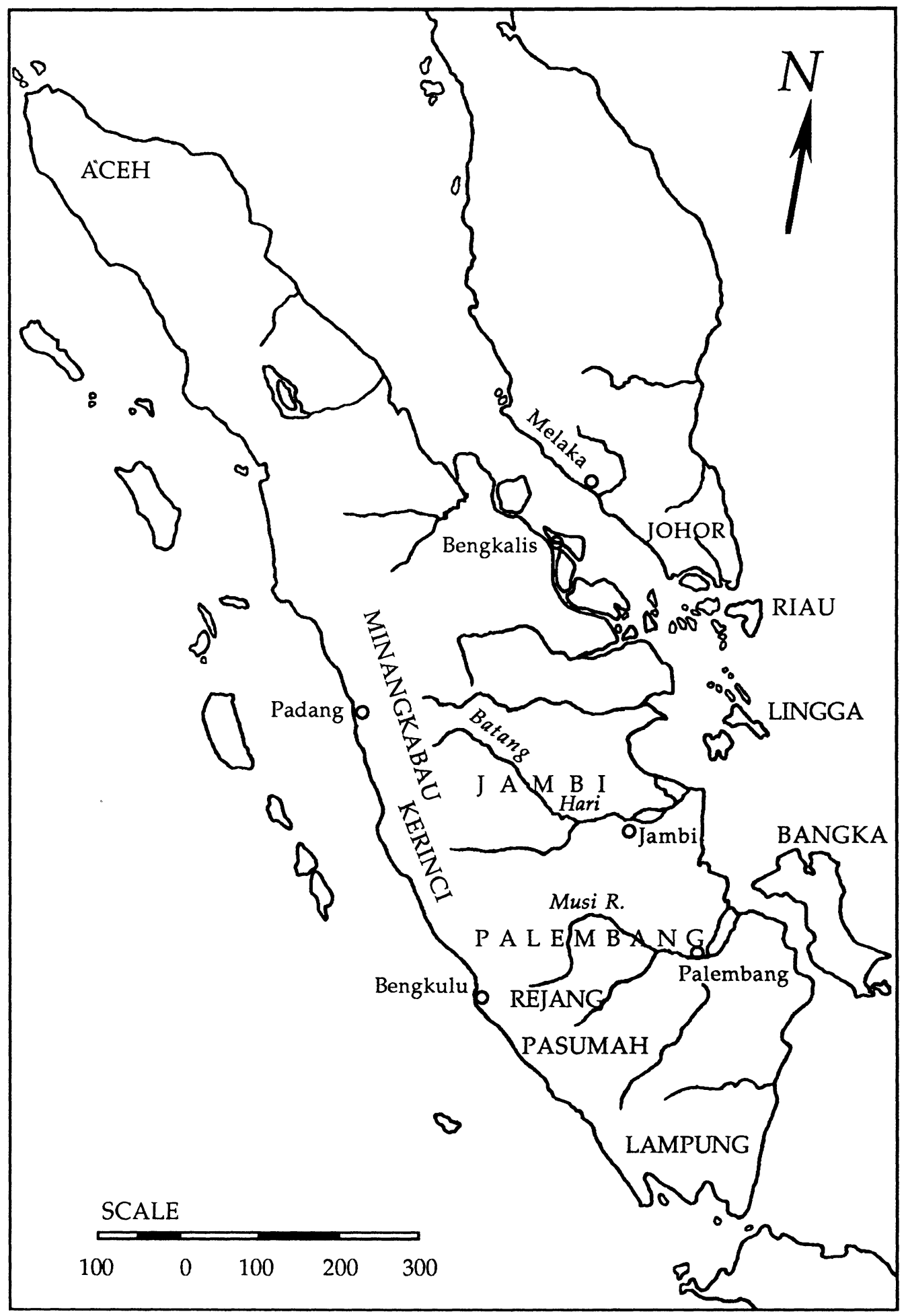

Sumatra and the Malay Peninsula 


\title{
The Cloth TRade In Jambi AND PALEMBANG SOCIETY DURING THE SEVENTEENTH AND EIGHTEENTH CENTURIES ${ }^{1}$
}

\author{
Barbara Watson Andaya
}

Anyone who has used Dutch East India Company (VOC) records ${ }^{2}$ will know that they are often stubbornly resistant to the historian's questions. The vast corpus of information they contain, however, has provided the basis for a number of detailed studies of regional history in the Indonesian archipelago. What such studies have shown is that generalizations regarding social and economic change during the seventeenth and eigh-

\footnotetext{
${ }^{1}$ A draft of this paper was originally presented at the Asian Studies Association of Australia Bicentennial Conference held at the Australian National University in February 1988. The research on which it was based is part of a larger study on the history of Jambi and Palembang ca. 1600-1800. Research has been made possible through financial support from Auckland University, the Japan Society for the Promotion of Science, and the Joint Committee on Southeast Asia of the Social Sciences Research Council and the American Council of Learned Societies with funds provided by the Ford Foundation and the National Endowment for the Humanities. I am also most grateful to the personnel of the Indonesian Institute of Sciences, the State Archives in The Hague, the Koninklijk Instituut, and Leiden University Library for invaluable assistance. Without support from so many people it would have been impossible to undertake this study, and to them all I would like to express my deep gratitude.

${ }^{2}$ The primary Dutch sources for this period are located in the Koloniaal Archief section of the Algemeen Rijksarchief in The Hague. The relevant material for this study is found in the records of the Verenigde Oostindische Compagnie (VOC), which includes the Overgekomen Brieven en Papieren, containing correspondence between Jambi and Palembang and the Governor-General and Council in Batavia. The letters and reports are bound in volumes each of which has a separate number preceded by the letter VOC. Between 1796 and 1800 the Company went into liquidation and its affairs were administered by a Committee. These records are found in the Archieven van het Comité tot den Oost Indische Handel en Bezettingen, 17961800 , abbreviated here as OIC. For the early nineteenth century material in the Archief van het Ministerie van Koloniën, 1814-1849 was used. Western manuscripts were also consulted in the Koninklijk Instituut voor Taal-, Land-en Volkenkunde in Leiden. They are catalogued as $\mathrm{H}$. (Handschrift), followed by the appropriate number. This library has an extensive collection of material in local languages catalogued under Ms.Or. (Manuscriptum Orientale). Reference is also made to the Oriental Manuscripts Collection of Leiden University Library, in which manuscripts are catalogued under the prefix Cod.Or. (Codex Orientalis), or under the name of a particular collection.
} 
teenth centuries should be made with caution, for variations in local conditions meant that the European intrusion could have very different results. An examination of the sources relating to the two Sumatran states of Jambi and Palembang over two hundred years has provided clear evidence that, although they both experienced a long association with the VOC, their respective fortunes varied considerably. At the beginning of the seventeenth century Jambi was considered, after Aceh, the most prosperous port in Sumatra, overshadowing its more populous neighbor Palembang. 3 Yet by the 1780 s Palembang had regained its position as one of the most prestigious states in the area while Jambi had sunk into a pirates' nest. As the following article suggests, local responses to the cloth trade during this period reflected the diverging economic environment; at the same time, the differing nature of these responses was also to affect the development of textile traditions in Jambi and Palembang in ways which are evident to the present day. In Jambi weaving had virtually disappeared by the early years of this century, ${ }^{4}$ while Palembang is still known for its distinctive sarongs woven from brilliant silk and dazzling gold and silver thread.

To a historian the persistence of weaving skills in the one culture and its demise in the other is intriguing, for in historical terms Jambi and Palembang have much in common. The two areas were apparently connected as early as the seventh century, and legends speak of the first rulers as brothers-in-law, married to the daughters of Demang Lebar Daun. Indeed, stories are still related of links between the two regions. Both were for a time subject to Javanese suzerainty, but, with their emergence as major pepper producers in the seventeenth century, they came into closer contact with Europeans and particularly with the Dutch East India Company. The royal families continued to intermarry, however, and in 1636 the ruler of Palembang agreed with the Dutch that Jambi and Palembang were "just like one body." $5 \mathrm{Had}$ it not been for Dutch intervention, Jambi would have been absorbed by Palembang in the mid-eighteenth century. Significantly, the sources suggest it was during this latter period, when Palembang's supremacy was asserted, that divergences in regard to demand for and production of local textiles first become apparent.

Until the eighteenth century what might be termed the "cloth context" of Jambi and Palembang was very similar. When the Portuguese and Spanish first came to Indonesia at the beginning of the sixteenth century, the two areas were already part of a long-standing trade network in which cloth played a vital role as an article of exchange. By the time the Dutch and English East India Companies were founded a hundred years later, it was well known that without cloth the spices of the East Indies-mace, cloves, nutmeg, pepper-would be unobtainable. The first fleet sent out by the VOC in 1604 was, therefore, instructed to establish factories in India even before going on to the Indies. Similarly the

${ }^{3}$ J. H. Glazemaker, trans., De Rampspoedige Scheepvaart der Franschen naar Oost Indien (Amsterdam: Rieuwertsz en Arentsz, 1669), p. 131.

4J. Tideman, Djambi (Amsterdam: Koloniaal Instituut, Mededeeling 42, 1938), p. 227.

5 O. W. Wolters, Early Indonesian Commerce: A Study of the Origins of Srivijaya (Ithaca: Cornell University Press, 1967), p. 241; Dagh Register gehouden int Casteel Batavia vant Passerende Daer ter Plaetse als over Geheel Nederlandts Indie (Batavia and The Hague: Bataviaasch Genootschap, 1887-1931), 1636, p.193; H.371 Koninklijk Instituut voor Taal-, Land- en Volkenkunde (henceforth KI), "De Kroniek van Palembang," n.p. Some of the legends linking the two can be found in Ceritera Rakyat Daerah Jambi (Jakarta: Department of Education and Culture, 1980/1), pp. 21-26, 47, 140. Other stories were also told to me during a visit to Bukit $\mathrm{Si}$ Guntang on the Sumai River in Jambi (January 1987). 
English East India Company directed the captains of its third voyage in 1607 to open up trade with Surat or the Red Sea ports prior to continuing to the archipelago. 6

Europeans in the seventeenth century simply accepted that cloth was essential for trade without concerning themselves about its cultural significance. They would not have understood why a silk cloth should be carved on the wall of a ninth century temple in Central Java, nor would they have known that in early Javanese inscriptions one of the ritual gifts most frequently mentioned is cloth. ${ }^{7}$ It is true that in 1618 the VOC added some yellow satin to its gifts of three pikuls of nails, two mirrors, and two balls of musk which were to be presented to the king of Jambi, but what he really wanted was black or green velvet. "Two years later it was still felt that an appropriate "honor" for the ruler of Palembang was "two pairs of silver spectacles, a Dutch cat and a picture of Amsterdam." 8

Seventeenth century Europeans took some years to appreciate that in most Indonesian societies, Jambi and Palembang included, textiles were much more than an item of dress or bedding. As part of institutionalized ritual exchanges, the presentation of cloth and clothing was a vital means of affirming the reciprocal relationships between individuals, families, clans, states-relationships which lay at the heart of Indonesian society. It was this cultural role of cloth which enabled the archipelago to absorb so many imported textiles. While exact overall consumption figures are impossible to supply, one can note that in 1652-1653 the VOC brought to Indonesia approximately 1,033,000 pieces, ${ }^{9}$ and to this must be added the extensive sales of Indian cloth by other Asian and European traders as well as imports from Europe and elsewhere in Asia.

Europeans might have been quicker to see the association between textiles and gifts had they come to Southeast Asia through the Pacific. It is useful to remember that, in many parts of Indonesia, clothes made of bark or plant fibers were then being worn for everyday use, with woven cotton or silk fabrics from India and China reserved for special occasions. Nor should we assume that weaving automatically produced a superior product, for much local barkcloth could well hold its own against the rougher cotton types. When he arrived in the Moluccas in 1521, Antonio Pigafetta described how the women of Tidore made cloth of beaten bark by soaking it in water until it was soft. "They then beat it with bits of wood and thus make it as long and as fine as they wish. It becomes like a veil of raw silk and has certain threads within it which appear as if woven." 10 By the late eighteenth century the wearing of barkcloth had virtually disappeared

${ }^{6}$ Holden Furber, Rival Empires of Trade in the Orient, 1600-1800 (Minneapolis: University of Minnesota Press, 1976), p. 34; T. Raychaudhuri and I. Habib, eds., The Cambridge Economic History of India, Vol. 1 c. 1200-1750 (Cambridge: Cambridge University Press, 1982), p. 388.

${ }^{7}$ H. W. Woodward, "A Chinese Silk Depicted at Candi Sewu," in Economic Exchange and Social Interaction in Southeast Asia: Perspectives from Prehistory, History and Ethnography ed. Karl L. Hutterer (Ann Arbor: Center for South and Southeast Asian Studies, Univ. of Michigan, 1977), pp. 233-43; Antoinette Barrett Jones, Early Tenth Century Java from the Inscriptions (Dordrecht: Foris Publications, 1984), p. 33.

${ }^{8}$ H. T. Colenbrander, Jan Pietersz. Coen. Bescheiden omtrent zijn Bedrijf in Indië, 7 vols. (The Hague: Nijhoff, 1919-23), 2: 389, 391; P. A. Tiele, "De Europeërs in den Maleischen Archipel," Section 9, Bijdragen tot de Taal-, Land-en Volkenkunde (henceforth BKI) 36 (1887): 248.

${ }^{9}$ Ruurdje Laarhoven, "The Textile Trade out of Batavia during the VOC period," Paper presented to the Asian Studies Association of Australia Bicentennial Conference, Australian National University, Canberra, February 1988, Table 1. I would like to acknowledge gratefully Ms. Laarhoven's willingness to answer a number of questions concerning the VOC cloth trade.

10 James A. Robertson, ed. and trans., Magellan's Voyage around the World by Antonio Pigafetta, 2 vols. (Cleveland: Clark, 1906), 2:89. 
in the western archipelago, except among more isolated groups who used it for work clothes. A contemporary observer, however, still commented on the similarity with the Pacific. "The original clothing of the Sumatrans is the same with that found by navigators among the inhabitants of the South Sea islands."11

The Pacific connection helps explain the tenacity of Indonesian attitudes towards textiles. The making of barkcloth is associated with early Austronesian society, and barkcloth beaters have been found in Neolithic grave sites from Taiwan to Java and the Malay peninsula. ${ }^{12}$ It can be argued that, as Austronesian-speaking peoples moved into Oceania from about $1300 \mathrm{BC}$, they brought with them not only the knowledge of how to make barkcloth ("tapa") but also the established attitudes towards it. In 1606 Luiz Vaez de Torres sailed to the East Indies from South America but did not encounter requests for cloth until he reached the Moluccas. However, his experiences show that in Oceania bark pounded to a smoothness resembling fabric played a similar function in honoring guests as did textiles in the Indonesian archipelago. Passing an island some way from New Guinea, he noted "a small canoe with only two men came to me to make peace, and presented me with some bark of a tree which appeared to be like a fine handkerchief, four yards long and three palms wide." And at the end of the eighteenth century missionaries in Tahiti commented on the ritual role of barkcloth, describing the "large quantities" which covered the ground at funerals, one chief alone presenting 35 bales. ${ }^{13}$

In the Indonesian archipelago, where weaving apparently began to develop about $3000 \mathrm{BC}$, existing attitudes and customs relating to barkcloth were simply extended to include "fabrics," initially made from native plants and trees like the fine mats of some Pacific islands. Here, indeed, the process of transferral is still going on. In parts of New Guinea women returning from their gardens traditionally covered their vegetables with embobi (a tapa cloth worn by females) if they passed a village in mourning. "To-day the custom survives but trade store cloth replaces embobi."14

Had Europeans been more familiar with Pacific traditions regarding tapa and woven mats they would probably have understood the Indonesian environment better. In both regions, for instance, cloth was particularly associated with women and with the lifegiving properties of females. Everything to do with cloth production was regarded as female. ${ }^{15}$ This was in marked contrast to India, where upper-class women had not been involved in weaving at least since Mauryan times, and where men's supervision of weaving had evolved into a domination by male guilds. Spinning may have remained

${ }^{11}$ William Marsden, A History of Sumatra (1811. Reprint; Kuala Lumpur: Oxford University Press, 1966), p. 49; M. A. Jaspan, Folk Literature of Sumatra (Canberra: Australian National University, 1964), p. 6.

${ }^{12} \mathrm{G}$. de G. Sieveking, "The Distribution of Stone Bark Cloth Beaters in Prehistoric Times," Journal of the Malaysian Branch of the Royal Asiatic Society 29, 3 (August 1956): 78-85; Peter Bellwood, Prehistory of the Indo-Malaysian Archipelago (Sydney: Academic Press, 1985), pp. 213, 214, 289.

${ }^{13}$ Richard Henry Major, "Relation of Luiz Vaez de Torres," in Early Voyages to Terra Australia (London: Hakluyt Society, 1859), p. 36; William Wilson, A Missionary Voyage to the Southern Pacific Ocean Performed in the Years 1796, 1797, 1798 in the Ship "Duff" (London: Missionary Society, 1799), pp. 39, 244.

14 W. Beattie ed., Iris, Tapa Cloth Maker (Goroka: Cultural Studies Committee, Goroka Teachers College, 1973), p. 11.

${ }^{15}$ Simon Kooijman, Ornamented Bark Cloth in Indonesia (Leiden: Brill, 1963), p. 58; Simon Kooijman, Tapa in Polynesia (Honolulu: Bishop Museum Press,1972), pp. 88, 107, 129. The literature is extensive on this topic, but a good introduction is J.M. van der Kroef, Indonesia in the Modern World, 2 vols.(Bandung: Masa Baru, 1956), 2: 142-52 and Mattiebelle Gittinger, Splendid Symbols. Textiles and Tradition in Indonesia (Washington, D.C.: The Textile Museum, 1979). 
in female hands, but the production of Indian textiles was controlled by men. ${ }^{16}$ In Indonesia and the Pacific the role of cloth as part of male-female duality not only kept weaving in the feminine domain, but imparted to it a particular role in religious ritual and imbued textiles with protective properties. In 1659, when a Dutch fleet attacked Palembang, two cannon draped with red cloth and blessed by imam stood outside the city. The people believed that their country so guarded was invulnerable. ${ }^{17}$ Similarly the sharing of textiles or clothing was thought to create a special and lasting bond between those concerned. In Palembang the legendary queen, Ratu Sinuhun, is said to have given the jungle dwellers, the orang kubu, their first clothes and to have then made them her subjects. ${ }^{18}$ Another folk story from Palembang relates how a legendary hero, Rio Raos, arrived in a downstream village to find the people divided into hostile groups. In order to bring about peace, Rio Raos gave them a present, a "kain [cloth] of the same design and color, made from the bark of one tree [sebatang kayu]." From then on the place was called Sekayu and the inhabitants lived as one. ${ }^{19}$ According to legend, when the ruler of Jambi wished to obtain jajah or tribute from the interior he sent four pieces of costly cloth, and as a sign of Jambi's relationship with Kerinci, cloth was divided and distributed to the federations of the "three cloth" and the "eight cloth" areas. ${ }^{20}$ The sending of a jacket "which my father himself wore" by the king of Jambi to the ruler of Johor in order to re-establish the cordial relations of their ancestors was thus an important political statement. 21

Southeast Sumatra, placed as it is on the southern approaches to the Melaka Straits, had from remote times been linked with international trade routes. Early contacts with China brought exposure to the silk and brocades of east Asia which became a prestige item in the region. In the twelfth century Srivijaya (commonly identified with the Palembang-Jambi area) was known as an importer of Chinese silk, and this fabric came to be particularly associated with the court. It was the growing demand for luxury fabric in Southeast Asia that Gujarati weavers were able to tap with their magnificent silk textiles, of which the patola and its imitations were most valued. 22

Increasingly, however, imports from overseas were finding markets outside elite circles. From the middle of the sixteenth century Jambi began to export pepper, and the principal medium for purchasing this valued spice was cloth, not of the luxury type but of a coarser quality which the pepper growers could afford to buy. The Chinese, in fact,

\footnotetext{
16 A. L. Basham, The Wonder that was India (New York: Grove Press, 1954), pp. 149, 180; Ramila Thapur, A History of India, Vol. 1 (Baltimore: Penguin, 1966), p. 113; Raychaudhuri and Habib, Cambridge Economic History 1: 77, 315.

17VOC 1229 John Truijtman's Daily Journal, Palembang, Nov. 1659, fol. 343.

${ }^{18}$ G. J. van Dongen, "De Koeboes in de Onderafdeeling Koeboestreken der Residentie Palembang," BKI 63 (1910): 189-90.

${ }^{19}$ Cerita Rakyat Daerah Sumatera Selatan (Jakarta: Department of Education and Culture, 1985), p. 16.

${ }^{20}$ Anon. "Korte Mededeelingen. Korintii," Tijdschrift voor Binnenlands Bestuur 46 (1914): 211; E. A. Klerks, "Geographisch en Ethnographisch opstel over de landschappen Korintji, Serampas en Soengai Tenang," Tijdschrift voor Indische Taal-, Land-en Volkenkunde 39 (1897): 16.

${ }^{21}$ VOC 1996 Jambi to Batavia, 23 March 1723, fol. 18; King of Jambi to King of Johor, Rec'd at Batavia 28 June 1723 , fol. 81 .

${ }^{22}$ Frederick Hirth and W.W. Rockhill, Chau Ju Kua. His work on the Chinese and Arab Trade in the Twelfth and Thirteenth Centuries, entitled Chu fan-chi (1911; New York: Paragon Book Reprint, 1966), p. 61; Gittinger, Splendid Symbols, p. 30.
} 
produced four different grades of silk, and the cheaper varieties would have been used to buy Jambi pepper. 23

But it was India which was without question the great producer of mass-market textiles in the seventeenth century. There were a number of reasons for the appeal of Indian cloth, not least the fact that technological advances in the subcontinent had considerably reduced the cost of manufacture. The Muslim entry into India in the fourteenth century brought the carding bow and possibly the spinning wheel, thus cheapening spun yarn and widening production. The numbers of weavers increased to cope with the larger quantities of yarn being produced; by 1620, for example, Masulipatnam had 7,000 weavers. Furthermore, Indian cloth was far more varied in pattern, color, texture, and size than were locally made Indonesian fabrics. At the upper levels Indian courts encouraged the expansion of luxury textiles, such as silk, sometimes in specially established factories. At the lower levels the specialization of different localities and sub-castes in one or another style meant that the common man could also choose from a range of designs and materials. As an example one could cite the English factory records from Bengal which list more than 150 different types. And in the seventeenth century Europeans themselves contributed to the variety of cloth available, as the trading Companies brought out their own skilled craftsmen from Europe to teach their Indian dyers how to produce certain colors. ${ }^{24}$

While basic Indonesian perceptions of cloth as "feminine" remained unchanged, the growing appeal and availability of Indian imports did bring some modification in the economic function of textiles in the archipelago. Amidst the discussion of symbolic and ceremonial roles, it is sometimes easy to forget that cloth had an actual worth as well. Its value as an exchange medium was especially apparent to Europeans in the seventeenth century when specie was scarce and when the common coinage was the shortlived Chinese lead picis. In some places, like Buton in Sulawesi, locally woven cotton rectangles were even used as currency, and two hundred years later in Sumatra it was still common to pay fines in cloth. ${ }^{25}$ Cloth had earlier established its advantage over picis and other coins because it was longer lasting, could not be bastardized, and as a consumer item could be used in a number of ways. When an individual died, therefore, any cloth or clothing in his possession was regarded as being of real worth. A Chinese peranakan (person of mixed blood) in Palembang in 1694 left such items as "a bundle of gold thread, 3 pieces of salampuri, 36 kain gulung, a small kris, a black silk robe, 18 gold buttons, various worn clothes, 4 pieces of thin silk cloth. ..." And when Sultan Ingalaga of Jambi died in Batavia in 1699, his son wrote to the Governor General to acknowledge the return of the dead king's clothes. ${ }^{26}$ The economic value of cloth was also reinforced by Dutch contracts. A treaty with Palembang in 1642, for instance, specifies that cloth may be

\footnotetext{
${ }^{23} \mathrm{H}$. Terpstra, De Factorij der Oostindische Compagnie te Patani (The Hague: Nijhoff, 1938), p. 118.

${ }^{24}$ Raychaudhuri and Habib, Cambridge Economic History 1: 77-81, 269, 282; K. N. Chaudhuri, The Trading World of Asia and the English East India Company 1660-1760 (Cambridge: Cambridge University Press, 1978), p. 275.

${ }^{25}$ Gittinger, Splendid Symbols, p.202; Marsden, History of Sumatra, p. 318; J. Kathirithamby-Wells, The British West Sumatra Presidency (1760-1785). Problems of Early Colonial Enterprise (Kuala Lumpur: University of Malaya Press, 1977), p. 109. In Jambi the orang kubu still feel it necessary to acquire piece goods in preparation for real or imagined litigation. A headman may have several hundred. Øyvind Sandbukt, an anthropologist working with the $k u b u$, kindly supplied me with this information.

26VOC 1557 Pangeran Aria of Palembang to Batavia, Rec'd 16 April 1694, fol. 64; VOC 1676, King of Jambi to Batavia, Rec'd 25 May 1703, fol. 6.
} 
used instead of money, and perquisites for Syahbandars and court officials (ruba-ruba and tombok) were made in carefully designated amounts of cloth. 27

By the seventeenth century the symbolic and real value attached to cloth made it the appropriate gift for every occasion, whether as payment, reward, or a symbol of homage. But in southeast Sumatra during this period the unprecedented expansion of pepper growing in the highlands, and the demand it made for sustained labor, must have deprived most peasant women of the time to weave more than was essential for family use. In the twentieth century observers also noticed that there was a marked drop in weaving among Jambi women as rubber production provided households with added income, 28 ard the same trend was apparent three hundred years earlier. It was easy to sell pepper, and more economical to buy cheap Indian imports which could be used to supply the cloth needed on so many occasions. One cannot but feel a sneaking sense of sympathy with a Dutch Resident who complained that, when the pepper growers came down from the interior, "I have to bring out a thousand guilders worth of cloth and when it is laid out they sit for half the day filling their bellies with tobacco and betel to buy just a few pieces. How can such people be merchants?"29

It was this expansion of the market at the lower levels which made the trade in textiles so profitable. In the early seventeenth century the English regarded Jambi as one of their best markets for Indian cloth; in 1691, even at a time of declining sales, the VOC still managed to dispose of nearly 18,000 pieces in Palembang, and this does not take into account the marked increase in Javanese imports. ${ }^{30}$ On every possible occasion cloth was presented-to a king at his installation, to nobles on being given appointments, to envoys, at a royal circumcision, to interior village heads, to the wife of a dethroned king, and especially by common men and women at the great life crises of birth, marriage, and death. The bonds established by this gift giving could be lasting. In the early eighteenth century, for example, a rebel Jambi prince was reported to be upstream distributing "new clothes" to interior groups to attract their loyalty, and it is understandable that a former ruler of Palembang, forced to flee to the hinterland, also took with him supplies of cloth. ${ }^{31}$ After a hundred years of trading in Jambi the Dutch knew better than to offer pictures of Amsterdam. In October 1717, for instance, the king and his entourage passed the VOC lodge on their way to make offerings at the graves of the royal ancestors. The list of gifts given is a testimony to the importance of cloth:

To the Queen Nyai Ratu, 2 pieces of tapih Jawa, 1 large and 1 small

To the King's newest wife, Ratu Mas, two pieces of sebagai leijleij

To the Crown Prince Dipati Suria Nagara, 1 armosin

To His Majesty's little daughter, 1 small tapih Jawa

To His Majesty's niece, Ratu Mas Rukmo, 1 sebagai leijleij

27J. E. Heeres,"Corpus Diplomaticum Neerlando-Indicum" Vol. I, 1596-1650 BKI 57, 3 (1907): 383, 409. The economic value of cloth has been stressed by Luc Nagtegaal, "Rijden op een Hollandse Tijger. De noordkust van Java en de V.O.C. 1680-1743" (PhD dissertation, Utrecht University, 1988), pp. 182-84.

${ }^{28}$ Tideman, Djambi, p. 227.

${ }^{29}$ Colenbrander, Coen, 7: 111.

${ }^{30}$ D. K. Bassett, "The Factory of the English East India Company at Bantam, 1602-1682" (PhD dissertation, London University, 1955), p. 153; VOC 1926 Calculation of profits on goods sold in 1691-1692, fol. 111.

${ }^{31}$ VOC 1808 King of Jambi to Res. of Jambi, Received 2 July 1711, fol. 99; VOC 1980 Palembang to Batavia, 3rd Register 23 Dec. 1722, fol. 3. 
To four concubines (bijwijven) of His Majesty, 4 tapih tulupakan 32

Europeans had by this stage come to appreciate something of the significance of cloth exchanges, and they understood that the financial rewards for those who could satisfy local demands were great. Dealing with the complexities of tradition and taste, however, remained a problem for VOC officials well into the eighteenth century. New Residents whose previoùs experience might have been somewhere in Java, the Moluccas, or the Malay peninsula found very specific tastes in southeast Sumatra. The long exposure to imported textiles had enabled local people to develop preferences among the bewildering array of Indian styles, which the English reportedly took about fifteen years to master. ${ }^{33}$ Miscalculations in ordering were inevitable. The case of one Dutch Resident, left with ten packs of sailcloth "which the merchants say is not used in Palembang," is not untypical, while another in exasperation complained of the "fastidiousness" of the Jambinese. $^{34}$

Part of this "fastidiousness" was due to traditional conventions regarding color. In the early seventeenth century the pepper-growing districts of the interior, largely peopled by Minangkabau, would not accept any cloth except black and white bafta, a cotton originally produced in Gujarat and only subsequently elsewhere. Black was used for ordinary wear, and while only the king or religious figures actually wore white, it was everywhere essential for funerals. The poorest individual aimed to set aside appropriate wrappings for his corpse, like two old orang laut who, captured by pirates, had been robbed of their few possessions which included "fifteen reals and two white cloths with which to bury themselves." 35

Red was another highly valued color, the difficulty in achieving a successful dye probably contributing to its reputation for protective qualities. The famed Hikayat Ali Hanaffiah, for instance, recited during the Portuguese attack on Melaka, declares that a piece of red cloth worn round the hero's forehead shielded him from all harm. During the Dutch siege of Palembang in 1658 the king's bodyguard had been dressed in red, and the royal cannon were draped in the same color. ${ }^{36}$ In dealing with the court, particular care was needed to observe the conventions associated with colors, because these were used, like batik patterns in Java in the eighteenth century, to distinguish rank. Yellow and white were reserved for royalty, and a failure to remember this could leave a Resident with unwanted stocks, such as "yellow Chinese belts which only the Javanese will buy." One king of Jambi was annoyed because officials in Batavia had wrapped VOC gifts to himself and to the princes in the same colored cloth. He also took offense when a letter to him from the Governor-General was wrapped in white fabric while one to the Crown Prince was in yellow; he interpreted this to mean that, in Dutch eyes, the heir was a more suitable ruler. 37

\footnotetext{
${ }^{32}$ VOC 1895 Jambi to Batavia, 13 Feb. 1717, fol. 11. See below, p. 46 for Glossary of Cloth Terms.

${ }^{33}$ Bassett, "Factory," p. 12.

${ }^{34}$ VOC 1808 Palembang to Batavia, 11 May 1711, fol. 35. For the Javanese case, see Nagtegaal, "Rijden op een Hollandse Tijger," p. 183.

35 VOC 1243 Jambi to Batavia 17 May 1663, fol. 361; VOC 3121 Jambi to Batavia 12 May 1764, fol. 16; VOC 1569 Jambi to Palembang 26 June 1695, fol. 126.

36Ismail Hamid, The Malay Islamic Hikayat (Kuala Lumpur: Universiti Kebangsaan Malaysia, 1983), p. 203; N. Macleod, "De Oost Indische Compagnie op Sumatra in de 17e Eeuw," Indische Gids 26, 1 (1904): 803.

37VOC 1728, Palembang to Batavia 11 June 1706, fol. 56; VOC 1926 Jambi to Batavia 30 June 1719, fol. 22, VOC 1854 Jambi to Batavia 16 Jan 1714, fol. 4. In Java, of course, yellow was also considered a royal color.
} 
Certain other colors were associated with the court because of their rarity. Whereas Europeans were struck by the "sky blue cloth" worn by Sumatrans in the early seventeenth century, Indonesians regarded it as an acceptable but common color. While indigo can be readily fixed to cotton, it is corrosive on silk and was therefore not found among luxury fabrics. Green, though also a problematic color because it could be achieved only by overdying, had a specific status in Islamic societies due to the belief that it was one of the shades worn by the Prophet. Only relatively few were entitled to wear it, and in Palembang this color was reserved for "the highest in the land."38

It is often said that Indonesians were conservative in their choice of textiles, but in Jambi and Palembang Europeans found the situation in many respects the reverse. For the Dutch a major problem was dealing with changing styles. In 1674 the Jambi Resident remarked that previously tapih serasah (multi-patterned skirt length) with flowers had been much desired, but now flowers were not so popular; in Palembang seven years later flowered cloth was still difficult to sell. ${ }^{39} \mathrm{New}$ designs would be eagerly bought up if they appealed and just as easily rejected if they did not, especially in Palembang where all types of piece goods were in high demand and the people insisted on "modish" styles. On occasion the Resident even sent samples of the preferred designs, or gave clear specifications such as "a pack of leusols [?], all painted except the borders and corner, without circles or decorations inside." Nor were the interior peoples left behind. Although only black and white bafta would sell in Jambi in 1616, upstream dwellers (orang ulu) gradually acquired a taste for other styles. Success depended on an ability to anticipate what the pepper growers might want and to set enough aside to guarantee sales, since they were likely to take their pepper elsewhere if cloth supplies were not to their liking. Such anticipation was not always easy. In 1677, for instance, the Palembang Resident noted in frustration that, although previously the orang $u l u$ had accepted rough and dark painted cloth, they now preferred "tulupakan, patola, sarasa and cambayer." 40

As well as pleasing local tastes the Dutch Residents also had to try and cater for those of incoming traders, particularly the Javanese and Makassarese. In 1666 the Jambi Resident reported that for the previous two years the Makassarese had not wanted chavoni, and he was left with stock which he was unable to sell. He found the Javanese also quite firm in their requirements; they would not take cloth with stripes at the head, or broad red stripes, and they now rejected large flowered designs which had previously been popular. Indeed, on several occasions Residents were driven to sending pictures of the desired styles and dimensions so that these could be specially procured in India. ${ }^{41}$

The inability of both the Dutch and (to a lesser extent) the English to keep pace with the market was accentuated in Jambi during the seventeenth century by the success of the Chinese. One could argue that this was in part due to a deeper understanding of the place of cloth in local society. A Chinese description of Palembang around 1618 notes that

\footnotetext{
${ }^{38}$ Isaac Commelin, Begin ende Voortgangh van de Vereenighde Nederlandtsche Geoctroyeerde OostIndische Compagnie, 4 vols. (Amsterdam, 1646), 1: 32; Jane Schneider, "The Anthropology of Cloth," Annual Review of Anthropology 16 (1987): 428; VOC 1895 Palembang to Batavia 16 Aug. 1717, fol. 70; Comité tot den Indische Handel en Bezittingen (henceforth OIC) 103, Palembang to Batavia 9 March 1795, np.

${ }^{39}$ VOC 1302 Jambi to Batavia 28 Sept. 1674, fol. 127; VOC 1361 Palembang to Batavia 2 Jan. 1681, fol. 5v; 31 Jan 1981 , fol. 16v.

${ }^{40}$ Colenbrander, Coen, 7: 112, 684; W. Ph. Coolhaas, Generale Missiven, 8 vols. (The Hague: Nijhoff, 19601985), 7: 398; VOC 1127 Jambi to Batavia 16 August 1638, fol. 467; VOC 1328 Palembang to Batavia 13 March 1677 , fol. 250 .

${ }^{41}$ VOC 1257 Jambi to Batavia 20 Oct. 1666, fol. 723; VOC 1105 Jambi to Batavia 7 Aug. 1632, fol. 244v-245v.
} 
"when a ship arrives here a present of fruit and silk is offered to the king." 42 There were in addition very practical reasons for Chinese prominence in the cloth trade. They dealt in smaller lots than the normal corge (pack of 20 pieces), and were prepared to take a much smaller margin of profit. Europeans noted with envy that the Chinese were even able to sell rough or damaged cloth and, being more flexible than the large trading companies, they could move quickly to respond to unforeseen demands, such as calls for stocks of white burial cloth following an epidemic. Unlike their European rivals, the Chinese were also willing to carry indebted Indonesians for several seasons until they could repay what they owed. 43

But in the cloth trade the Chinese had one overwhelming advantage; they had women to assist them. In most areas of Indonesia the hawking of cloth was commonly the work of women, and it may have been common practice (as in Banten), to set aside a section of the pasar for them. In both Jambi and Palembang, where women bought from the Dutch, they can be seetras the "retail arm" of the market. But in neither place did the Dutch establish a comfortable relationship with the local "coop vrouwen" (women traders). In Palembang the latter refused pointblank to come into the Dutch lodge, apparently afraid of a close association with men whose treatment of native females was notorious. They would only trade if sales were made from rafts or perahu anchored on the river near the lodge. The Dutch certainly had female slaves, but I found no record of their being used in cloth sales. The Chinese, on the other hand, "bought wives" when they arrived, and, as one observer noted in Banten, these women "served them until they returned to China." In Jambi and Palembang most Chinese adopted Islam and married local women, who supervised their cloth shops and went with them during trips to the interior. ${ }^{44}$

The association of Chinese with local women and the involvement of peranakan Chinese in the cloth trade gave them a distinct advantage over the Europeans. Their success was so pronounced that both English and Dutch reluctantly began to "trust out" cloth, that is, to advance supplies to Chinese to take upstream to exchange for pepper. A list dated 1624, less than a decade after the Europeans had established posts in Jambi, shows that the VOC had given out 1,100 pikuls of cloth to the Chinese, and by the mid 1630 s it was said that the interior people were so accustomed to Chinese peddlers in upstream districts that it was unlikely they would ever come down again to sell their pepper. ${ }^{45}$

If the Dutch had difficulties satisfying the market at the lower levels, their problems were even greater when dealing with the court. This was especially true in Jambi where until 1679 the English also maintained a lodge. From the time of their arrival in Jambi the English had made a point of cultivating royal women. The Dutch felt their rivals

\footnotetext{
42 W. P. Groeneveldt, "Notes on the Malay Archipelago and Malacca Compiled from Chinese Sources" Verhandelingen van het Bataviaasch Genootschap van Kunsten en Wetenschappen (henceforth VBG) 39 (1880): 75. For similar comments on Banten, see Leonard Blussé, "Western Impact on Chinese Communities in Western Java at the beginning of the 17th century," Nampo Bunka, Tenri Bulletin of South Asian Studies 2 (1975): 29.

43 VOC 1138 Jambi to Batavia 12 March 1642, fol. 586; VOC 1080 Jambi to Batavia 17 Dec. 1623, fol. 359; VOC 1098 Jambi to Batavia 24 Sept. 1629 fol. 6.

${ }^{44}$ Blussé, "Western Impact," p. 29; VOC 1338 Palembang to Batavia 25 Oct. 1678, fol. 373; VOC 1267 Jambi to Batavia 7 April 1668, fol. 537.

${ }^{45}$ VOC 1083 Jambi to Batavia 2 Aug. 1624, fol. 240v; Bassett, "Factory," p. 103; W. Ph. Coolhaas, Generale Missiven (The Hague: Nijhoff, 1960), 1: 541.
} 
had gained such commercial advantages that in 1626 a contract was signed by which neither party would present gifts to the king or the court ladies. But the English continued to be particular favorites of the king's mother, the Ratu Mas, and it was reported that they even maintained women in their lodge in order to attract the king's custom. With closer links to court circles, the English were consistently more successful than the Dutch in 'catering to the fashion of the women's quarters by supplying cloth which was of better quality and "more luxurious." This was in part a reflection of a change in policy by the English East India Company, which from 1665 concentrated more on fine textiles. Increasingly VOC Residents faced complaints from the rulers of Jambi and Palembang that they had failed to lay in stock of "richer and more fashionable cloth." 46

The demands from the court were not simply due to what the Dutch considered the unbridled luxury of the noble women. As the century wore on, increasingly more Indian cloth was reaching the interior. In 1673 it was estimated that in Palembang about a third of the cloth which the VOC imported went to the "bovenlanden," and, despite European attempts to dominate the textile trade, much Indian cloth was also brought in by local traders via secondary rivers and jungle paths. ${ }^{47}$ Orang $u l u$, who might once have been contented with rough or painted textiles, now began to demand superior fabrics, and occasionally even silk. As their subjects gained access to a widening variety of cloth types, the kings of Jambi and Palembang were forced to seek out more exotic or unusual textiles, not merely for their own use but to send as gifts to neighboring courts. The staples of cloth trade-bafta, tulupakan, tapih serasah-were not enough to satisfy an elite whose taste ran to velvet, satin, fine muslin, and gold embroidered kain gulung. Now kings began to demand first choice of any incoming cloth, even fining anybody who bought up pieces before them; the court circle also began to specify the kinds of textiles which they considered would set them apart from their social inferiors. In 1663 the Resident in Jambi complained that, although the Pangeran Ratu was always expressing his goodwill to the Dutch, "his principal aim is to obtain rare cloth, velvet, braid and lace." 48 He noted that gold alegia, gold braid with studs, gold lace with spangles, fine chintz were regarded as "unusual items," and were much more esteemed as gifts than "more common cloth of greater value." Thus the Governor General might receive a request from the ruler of Palembang for a flowered Surat cloth "inlaid with ivory" like one he had been shown by an Armenian merchant, or a letter from the king of Jambi asking for a Japanese gown with long sleeves, "because I have many with short ones," or for dark purple velvet from Holland. The women also put in their order for "robes of thin cloth with gold and spangles," for Dutch silk, for fine yellow, blue, and green calico, for gold lace, and printed gold chintz. ${ }^{49}$ Supplies of high quality Indian fabrics "suitable for kings" were particularly necessary during weddings, not merely for the clothes of the participants but for the ritual exchanges between bride and groom which occurred on these occasions. Standards for such gifts were high, and a supply of salampuri (calico) sent by

\footnotetext{
46VOC 1098 Agreement between Dutch and English, Jambi, 4 May 1626, fols. 17-18; VOC 1226 Jambi to Batavia 15 Oct. 1658, fol. 557; VOC 1407 Jambi to Batavia 7 Nov. 1684, fol. 2792v; Dagh Register (1634), p. 44; Kristof Glamann, Dutch-Asiatic Trade 1620-1740 (The Hague: Nijhoff, 1958), p. 141.

47 VOC 1294 Palembang to Batavia 22 Feb. 1673, fol. 332v.

${ }^{48}$ VOC 1243 Jambi to Batavia 18 March 1663 , fol. 345.

49VOC 1246 Jambi to Batavia 22 Feb. 1664, fol. 174; VOC 1125 Palembang to Batavia 15 Jan. 1637 fol. 520v; VOC 1226 Jambi to Batavia 15 Oct. 1668, fols. 552v, 559.
} 
Batavia could easily be rejected because the decorative rosettes were "a hair" too large. 50 One Palembang ruler specifically asked for trading privileges so that he might sell pepper outside the Dutch monopoly. A prime purpose of such transactions was to buy appropriate cloth for royal gifts in ports such as Kedah and Aceh, which were still frequented by Indian traders. ${ }^{51}$ One of the Indian textiles which had come to be traditionally presented was that known as kumitar, an expensive batikked cotton. So vital was this fabric for the performance of the wedding ceremony that in 1777 a court marriage in Palembang was postponed so that kumitar could be purchased in Batavia. 52

The seventeenth century, therefore, saw in both Jambi and Palembang a widening use of imported textiles, stimulated by the ready availability of cloth, a growing cash economy, the demands of pepper cultivation on female labor and, above all, by the deepseated attitudes which made cloth a principal item of exchange not just in rituals associated with life crises but in establishing working relationships between individuals. Indian weavers and dyers had shown a great ability and willingness to respond to Indonesian demands, encouraging the development of particular regional tastes. And the combination of bright colors, shimmering cloth such as silk, and gold decorative work had become particularly favored by the courts of both Jambi and Palembang.

In the last quarter of the seventeenth century, however, the situation began to change, and in the process the textile traditions of both Jambi and Palembang were directly affected. In Palembang in 1681 and in Jambi in 1683 (following the departure of the English in 1679), the VOC obtained a monopoly of Indian cloth. By the contracts signed in those years it was illegal for any other traders except the VOC to bring in Indian textiles, unless they had been purchased from the Company. The limitations this imposed on the variety of imports aroused strong resentment among the women of the courts, who were the keenest buyers of exotic cloth. They were not placated by Dutch concessions which allowed the king to import annually 120 pieces (6 corge) of "cloth worked with gold and silver thread" for his own use. ${ }^{53}$ Increasingly, royal women began to send their own ships out secretly to ports such as Riau, Melaka, Batavia, and Macao to buy up supplies of textiles which suited their tastes. So active was the dowager Queen of Palembang that one Dutch Resident described her as an "experienced coopwijf." 54

But in the late seventeenth century even those who successfully evaded VOC patrol boats to buy their cloth elsewhere would have found an unwelcome trend. The prices of Indian textiles were rising. The reasons are not altogether clear, but it has been shown that in India from the 1690s the cost of living was increasing. Higher prices were first apparent in Coromandel textiles and, although cloth production in Bengal expanded to supply cheaper piece goods, it was not long before the pattern of spiralling costs became evident there as well. The commercial life of Surat was also declining, and in 1702 its textiles cost 20 percent more than in the previous year. Through the eighteenth century Indian producers faced growing competition from European cloth in traditional markets

50VOC 1267 Jambi Journal, 18 July 1668 , fol. 559.

51 VOC 1776 Palembang to Batavia, 1 Oct. 1709, fol. 3.

52 VOC 3494 Palembang to Batavia, 28 July 1777 n.p. : I am indebted to Ms. Ruurdje Laarhoven for the explanation of kumitar."

53J. E. Heeres, "Corpus Diplomaticum Neerlando-Indicum" Vol. 3, 1676-91, BKI 91 (1934): 326.

54 VOC 1414 Jambi to Batavia 30 June 1685, fol. 234; 26 Nov. 1685, fol. 246; VOC 1369 Palembang to Batavia 24 Oct. 1681, fol. 900v; VOC 1498 Palembang to Batavia 22 June 1691, fol. 86. 
such as Africa. All these developments combined to push up the price of Indian piece goods. In Madras, for example, cloth prices in 1740 were almost double those of 1660.55

For Indonesians buying from Dutch middlemen the inflationary trends were even more marked. By the 1690s the cost of Indian textiles in Jambi and Palembang had risen by 8-10 percent, and the pattern continued through into the eighteenth century. This was exacerbated because the VOC maintained or even increased its profit margin, sometimes selling cloth for as much as 1.5 times the original purchase price. In 1712 a popular calico, the Bengal garra, brought a general profit in Palembang of 117.25 percent, and this was at a time when the VOC wage for coolies had remained .25 Spanish real for nearly a century. Furthermore, there were complaints that the quality of piece goods sold by the Dutch was declining, even in luxury fabrics where copper might be substituted for gold thread. Purchases of Indian textiles reflected Indonesian dissatisfaction with rising prices and poorer quality. In 1717-1718 VOC sales in Palembang were half those in 1691, and the Palembang ruler appealed to Batavia for help in buying cloth "suitable for kings and princes to wear." Even more significantly, although the Dutch continued to give Indian cloth as gifts, by the 1770s the Palembang Syahbandars were receiving payment in cash only. ${ }^{56}$

The rise in the cost of Indian textiles coincided with a second development in southeast Sumatra-a drop in pepper prices. In 1621 both English and Dutch had contracted to pay 7.5 reals the pikul and other traders often paid more; at the end of the seventeenth century, under the Dutch monopoly, the price had sunk to 3 reals the pikul. Furthermore, in both Jambi and Palembang kings had sought to arrogate interior trade to themselves with the appointment of jenang, or royal representatives, who took cloth and salt and traded them for pepper at fixed, low prices.

The response to this was predictable. The interior peoples returned to growing cotton, which they had abandoned in favor of pepper but which was now preferred because it could be either consumed locally or sold to incoming traders. This trend so disturbed the Dutch that in the 1730s they persuaded the rulers of both Jambi and Palembang to order all cotton bushes destroyed. Judging by the amounts of cotton still being carried to other ports, this move was manifestly unsuccessful. With cotton available in greater quantities, there was also a noticeable increase in weaving which in purely economic terms was justified by the higher prices of imported goods. The trend aroused particular comment in Jambi where trade was declining markedly, and, in the words of the Resident, "there are as many looms as there are households." 57

Had southeast Sumatra been more isolated from established trade routes the increase in local weaving might have had quite different results. At the beginning of the nineteenth century, for instance, an Englishman visited Sungai Tenang on the Kerinci-Jambi

\footnotetext{
55 S. Arasaratnam, Merchants, Companies and Commerce on the Coromandel Coast, 1650-1740 (New Delhi: Oxford University Press, 1986), pp. 272, 336-41; Om Prakash, The Dutch East India Company and the Economy of Bengal 1630-1729 (Princeton: Princeton University Press, 1985), p. 144; Ashin Das Gupta, Indian Merchants and the Decline of Surat C. 1700-1750 (Wiesbaden: Steiner, 1979), pp. 7-8.

56 VOC 1557 Palembang to Batavia 15 March 1694, fol. 56v; VOC 1926 Calculation of profits on goods sold in 1691-1692 and 1717-1718, fols. 131, 111, 137; VOC 3442 Palembang to Batavia 16 June 1775, fol. 85; VOC 1759 Palembang to Batavia 8 Sept. 1708, fol. 76; VOC 2029 King of Palembang to Batavia, Received 25 Sept. 1725, fol. 45.

57VOC 1569 Jambi to Palembang 7 May 1695, fol. 106. The return to weaving was also noted in Banten when cloth supplies were short. M. A. P. Meilink-Roelofsz, Asian Trade and European Influence in the Indonesian Archipelago between 1500 and about 1630 (The Hague: Nijhoff, 1962), p. 244.
} 
border, which then as now was relatively difficult of access. While cheap cloth obtained from coastal centers was widely worn, there was still evidence here of a distinctive local weaving style. "The men are very fantastical in their dress. Their bajus [short jackets] have the sleeves blue, perhaps, whilst the body is white with stripes of red or any other color over the shoulders and their short breeches are generally one half blue and the other white, just as the fancy leads them." 58

But in the late seventeenth century the entire coast of Jambi and Palembang, and indeed most of the interior, was firmly locked into a commercial network which had flourished for centuries and which ultimately focussed on Java's northeast coast, the major source of rice and salt. Declining prices for pepper and other spices and the rising cost of Indian textiles coincided with, and probably stimulated, the great rise in the output of Javanese cloth. Rough cloth from Java was already being imported to Palembang and Jambi when the Dutch and English arrived, but it does not appear to have been popular except at the lower levels, where it appealed because of its cheapness. The ruler of Jambi did in 1642 order anyone appearing in his presence to wear Javanese dress as part of a "Javanization" campaign, aimed at winning Mataram's favor and perhaps prompted by Sultan Agung's earlier command that only batik should be worn at court. Javanese cloth, however, could not compete with Indian imports in the luxury market, and it did not begin to pose a real challenge even at the lower levels until the economic shifts of the $1680 \mathrm{~s} .59$

The trend in the late seventeenth century can clearly be seen in Java where local textile production was increasing. By the 1680 s Javanese favored their own "painted cloth" over imported Coromandel textiles. ${ }^{60}$ In 1683 the cargoes of Javanese cloth arriving in Jambi and Palembang had become so great that there was a short-lived attempt by the Dutch to extend their monopoly of Indian fabrics to cover all cloth. The great attraction of Javanese imports was the price. Whereas the Dutch sold Indian piece goods for an average of 1-2 reals, those from Java could cost as little as .25 real each and were even said to be of superior quality and more durable than their Indian counterparts. In 1691 when a Dutch envoy visited Palembang he noted that most of the men "from the king to the lowest peddlers" were wearing Javanese and Madurese cloth. Though most were termed "gobar tsjankring [canting?]" he distinguished a number of styles. Two popular designs featured "blue flowers with tendrils" and "a purple background with sprinkles." Another smaller cloth was called simply batik, "rough blue flowers on a white ground" which was mostly worn by children, as was another Madurese type, white and thin, called sampan. 61

From the early eighteenth century the increasing amounts of imported Javanese cloth are clearly apparent in Palembang shipping lists. While these figures do not represent all the textiles brought by Indonesian traders, since they do not include "smuggled" cargoes, they must be given serious attention because they gave a clear indication of trends in regional trade. Let us take two sample months, those of September-October,

\footnotetext{
${ }^{58}$ Marsden, History of Sumatra, p. 323; Klerks, "Geographisch en Ethnographisch opstel," p. 107.

${ }^{59}$ Dagh Register, 1636, p. 84; P. A. Tiele, Bouwstoffen voor de Geschiedenis der Nederlanders in de Maleischen Archipel, 3 vols. (The Hague: Nijhoff, 1886-1895), 3: 114; Merle Ricklefs, Modern Javanese Historical Tradition (London: School of Oriental and African Studies, 1978), p.37.

${ }^{60}$ Tapan Raychaudhuri, Jan Company in Coromandel 1605-1690 Verhandelingen van het Koninklijk Instituut 38 (1962): 162.

${ }^{61}$ VOC 1498 Isaac van Thije to Batavia 22 June 1691, fols. 60v-61v.
} 
when vessels from Java first began to arrive. In 171964 corge of Javanese cloth are listed for this period, including 12 described as "painted." By 1758 the amount has reached 728 corge, not including additional supplies of Madurese and Balinese cloth. Over 400 corge are given for October of that year, among which are 60 clearly identified as "batik." The pattern continues through the century so that, in September-October 1793, 2,745 corge of Javanese cloth are tisted as reaching Palembang, one vessel alone bringing 600 corge. 62

The dramatic increase in Javanese imports in the latter half of the eighteenth century is also due to the fact that, after 1770, all private trade to destinations north of Melaka was forbidden, thus depriving the Palembang market of cloth from Siam and Cambodia which had helped fill the gap created by the decline of Indian textiles. ${ }^{63}$ In 1719 , for instance, only one corge of Cambodian cloth was brought in between January and April, but during the same period in 1759, 515 corge of Cambodian cloth and 255 of Siamese arrived in Palembang. ${ }^{64}$ With the drying up of this source, an even greater need was created for textiles from Java.

Despite the obvious popularity of Javanese cloth and despite an increase in local cotton weaving, there remained a group that was not satisfied and that still preferred the bright colors, the gold embroidery and the fine silk typical of Indian textiles. These were the court women who were still the major purchasers of Indian piecegoods, even when their men had begun wearing cloth from Java. ${ }^{65}$ It appears that, as the amounts and standard of Indian cloth declined, court women increasingly began to weave their own high-quality fabric.

In itself, weaving by noble women was not a new development. Some weaving had always been done in the court, because it was considered a female accomplishment and because cloth woven by royal women was felt to have a special significance. Cindur Mata, the Minangkabau hero who recurs frequently in Jambi folk stories, is reputed to have set off on his travels in trousers woven by the daughter of the king of Bengkalis, a sarong made by the daughter of the king of Johor, and a headcloth given by the daughter of the king of Siam. In the seventeenth century royal women in Jambi and Palembang had occasionally asked for gifts of gold thread, even specifying the desired thickness. Imports of gold thread and raw silk from China are intermittently mentioned, and in 1640 the ruler of Jambi presented the Dutch Resident with "a gilded silk cloth" woven by his wife. ${ }^{66}$

Because of the presence of weaving skills in Jambi and Palembang and the similarity in background between their ruling classes, one might have expected a similar response in both courts to the gap in the textile market which began to open up in the eighteenth century. However, it was in Palembang that the weaving of high-quality luxury fabrics by noble women became established. I would argue that this was because the economic and political situation in Jambi was now quite different from that in Palembang. When the Dutch and English had first arrived in the area they had commented on Jambi's "rich

\footnotetext{
${ }^{62}$ These calculations are made from the lists of ships arriving and leaving Palembang in 1719 (VOC 1926, fols. 32-99), 1758 (VOC 2934, fols. 38-78 and VOC 1965, fols. 3-15), and 1793 (OIC 103). I must emphasize, however, that comments are based on an examination of all shipping lists from Palembang between 1719 and 1796.

63 VOC 1024 Batavia to Palembang 30 April 1770, fol. 94.

${ }^{64} \mathrm{VOC} 1498$ Isaac van Thije to Batavia 22 June 1691, fols. 60v-61v.

${ }^{65}$ See footnote 62 above.

${ }^{66}$ Dagh Register, 1640, p. 110; VOC 1236 Jambi to Batavia 26 Oct. 1661, fol. 696; J. L. O. van der Toorn, "Tjindoer Mato. Minangkabausche-Maleische Legende," VBG 45, 2, (1891): 20-21.
} 
and luxurious" court. A hundred years later this same court was poverty stricken, with nobles heavily in debt. VOC textile sales reflect their impecunity. In 1684 five packs of kain gulung, an expensive but previously desired cloth, had found no buyer even after two years, and by 1695 when two Banten ships brought in 100 corge (about 2000 pieces) it was enough to supply Jambi's entire trade for three years. 67 Continuing wars fought by Jambi from the 1670s, internal rebellion, the decline in pepper prices and production, and the subsequent departure of the Chinese had all combined to impoverish the king and the ruling classes. Though the Dutch left in 1770 Jambi was in no position then to benefit from the consequent removal of trading restrictions.

In Palembang, on the other hand, a more peaceful political situation contributed to a far stronger economy. Trade in forest and jungle products flourished and, although pepper growing was in decline, the comparative figures speak for themselves. In the 1695 book year Palembang produced 1,895,066 pounds of pepper for the Dutch, and in the twelve months to February 1695 the VOC made a profit of f.25,684. In Jambi, on the other hand, the profits were only f.945. Palembang Residents now began to stress the king's great wealth which "increases yearly."68 The prosperity of Palembang was enhanced further following the commercial development of tin on Bangka after 1719. As a royal monopoly, tin brought such profits to the royal coffers that, according to William Marsden, the king of Palembang "must be possessed of treasure to a large amount," and Stamford Raffles believed the Sultan to be "one of the richest of the Malay chieftains \{who\} is literally said to have godowns stored with dollars and gold hoarded by his ancestors. ..."69

Palembang's prosperity fostered a wealthy court that could well afford to buy imported raw silk and gold thread with which to create its own alternatives to the declining Indian trade in luxury goods. The evidence indeed suggests that, from the middle of the eighteenth century, imports of these items into Palembang began to expand. The VOC shipping lists for 1718-1719 and 1722-1723 show that no raw silk was brought in legally, and only small amounts of gold thread. By 1759 there was a noticeable increase, with 275 tubs of gold thread and 35 tubs of raw Chinese silk being noted among imports between January and April, despite edicts in China prohibiting raw silk exports. ${ }^{70}$ I have already suggested that this increase was in part to satisfy specific local tastes, primarily in court circles, but the satisfaction of these demands now assumed greater importance because it appears to have coincided with changes in court protocol concerning dress. According to one Palembang account, it was during the eighteenth century that the wearing of tubular tajong or sarong, as opposed to the loose-flowing Javanese kain, became mandatory for males. "All the people in Palembang and the upstream areas of its nine tributaries changed clothes to wear tajong and sarong, according to the orders of the Raja in Palembang. Previously everybody had worn long kain in the Javanese style [i.e. wrapped around the body] but now the Raja ordered that women should continue to wear the long kain and men were to change to tajong or sarong. The country was now established in the new custom regarding dress." While the meaning of

67VOC 1099 Jambi to Batavia 1 Jan. 1630, fol. 117v; VOC 1403 Jambi to Batavia 17 Feb.1684, fol. 303v; VOC 1569 Jambi to Palembang 8 January 1695, fol.49.

${ }^{68}$ Coolhaas, General Missiven (1975), 5: 720, 739; VOC 1498 Isaac van Thije to Batavia 26 Feb. 1691, fol. 13.

${ }^{69}$ Marsden, History of Sumatra, p. 361; John Bastin, "Palembang in 1811," BKI 109, 4 (1953): 307.

${ }^{70}$ Calculations were made from the list given in fn. 62 plus those from 1722-1723 (in VOC 2013, fols. 38-114 and VOC 2051, fols. 16-42. See also Fu Lo-Shu, ed., A Documentary Chronicle of Sino-Western Relations (16441820) (Tucson: Association of Asian Studies, University of Arizona Press, 1966), pp.226-27. 
tajong in this context is not completely clear, it is differentiated from sarong and one authority has suggested that it could be translated as "silk sarong." Certainly local legend remembers the first half of the eighteenth century as a time when weaving, notably with silk, was actively encouraged at court. These developments have been particularly associated with the reign of Sultan Mahmud Badaruddin (1722-1757) and may have been encouraged by a subsequent relaxation of Chinese policies regarding silk exports via Batavia. ${ }^{71}$ By the last days of the Palembang sultanate when another Sultan Mahmud Badaruddin (1804-1812, 1818-1821) acted as a particular patron of the arts, the trade in Chinese raw silk brought from Siam, China, Singapore, Lingga, and Riau was valued at around f.9,940, and in the same year 75 containers and 25 packs of gold thread worth more than $f .583$ were also imported. ${ }^{72}$

There are also hints that the greater use of locally produced silk textiles may have been due to an improvement in color quality as dyeing techniques incorporated new methods. In 1691 a Dutch observer in Palembang, describing the varieties of Javanese cloth, had remarked that these were rarely washed; this was probably because of the tendency of dyes to fade. But ninety years later another visitor commented on the dyefast qualities of the "silk cloth with small flowers or checks" now being produced by Palembang women. "They know how to prepare and deal with silk so that it not only holds its color longer but can even be washed."73

Quality dyeing would have been important because of the place of color in denoting court rank. A Palembang court document dating from 1792 lists the marks of dignity at court, specifying the color, design, and material of clothing, umbrellas, flags, and the decoration for perahu. One is left with the impression that court occasions were marked by a profusion of bright color-red, orange, gold, green-most prominent among which was the fine yellow silk (lungsir) which was the prerogative of the royal family. ${ }^{74}$ The same document also implies that only when an individual donned clothes of the correct style and color was the full authority of office assumed and his rank openly demonstrated. Some nobles, for example, were entitled to banners with the motif of a monkey, while others had a garuda, a lion, a tiger, or a naga. The same theme is echoed in another Palembang manuscript, which lays down that, whereas menteri wear kopia (a tall fez-like cap) decorated with gold thread, pangeran and penghulu were only entitled to silver thread. ${ }^{75}$

Added together, European accounts, local legends, and written manuscripts suggest that during the eighteenth century in Palembang there was an increased emphasis on

\footnotetext{
${ }^{71}$ Cod.Or. 7653a, Leiden University Library. Untitled. Miscellaneous Material from Palembang, fol. 110; Fu, $A$ Documentary Chronicle, pp. 235-36. I am indebted to Radin Husin of Palembang, a noted local authority, for information regarding court culture in the mid-eighteenth century. The definition of "tajong" has been taken from T. Iskandar, Kamus Dewan (Kuala Lumpur: Dewan Bahasa dan Pustaka, 1970), p. 1162, while Dr. J. Collins and Dr. J. Prentice kindly offered their thoughts on the tajong/sarong distinction.

${ }^{72}$ The figure would in fact have been much higher, since the value of 5 pikuls of raw silk and 48 chests of gold thread from China was not given in the source. 3075 Archief van het Ministerie van Koloniën 1814-49 "Statistiek van den Handel, 1822," n.p.

${ }^{73}$ VOC 1498 Isaac van Thije to Batavia 22 June 1691, fols. 60v-61v; J. C. M. Radermacher, "Beschryving van het Eiland Sumatra, in zoo verre hetzelve tot nu toe bekend is," VBG 3 (1781): 127.

${ }^{74}$ Berg Collection 146, Leiden University Library, fols. 4-5. Kindly translated from the Javanese by Pak Marzuki Ahmad.

${ }^{75}$ Ms.Or. 76 Koninklijk Instituut, "Alamat ini Sila-Sila Raja-Raja Didalam Negeri Palembang," fol. 35; C. F. E. Praetorius, “Eenige Bijzonderheden omtrent Palembang," De Indische Bij 1 (1843): 396.
} 
court dress as a means of denoting social relationships, and that in this context the weaving of silk was particularly important. However, the sources reveal little of the women who would have been involved in this specialized activity, although tradition maintains that during the eighteenth century the women's quarters of the Palembang kraton were a focus for artistic activities. Romances in refined classical Javanese are known to have been written under the patronage of princesses, and much of the fine woodcarving found in the kraton was reputed to be the work of women. Their tastes would thus have helped shape stylistic developments. The distinctive red-gold combination typical of silk weaving in Palembang may possibly be due to Chinese influence, since within court circles women of high rank were frequently of Chinese descent. Of the wives of Sultan Mahmud Badaruddin (1722-1757), for example, three are known to have had Chinese fathers and one was from the Chinese community of Semarang. In the eighteenth century Arab influence in Palembang also increased, as Sayids from the Hadhramaut began to settle in the capital and to marry royal women, and their preferences may have reinforced the Islamic influence which can be discerned in many Palembang designs. The close commercial and cultural connection with Java would probably also have encouraged the limited batik work which is said to have been carried out by the Sultan's women. Designs were often called after the artist; the motif on one piece, for instance, is called "Keramjaya" because it was created by the wife of Pangeran Keramjaya. ${ }^{76}$

Nor was it just noble women who were exposed to these developments. Much of the textile production in the kraton would have involved females from interior districts, who were attached to the court because of the custom of sending women to the king as an acknowledgement of an area's subservience to the center. Outside the palace, colors and styles worn in court circles were adopted in a modified form by ordinary people, particularly for festive occasions. For those who could not afford silk it was possible to have a cheaper imitation, cloth which had been "given a gloss by damping it with ricewater and then rubbing it with a certain seashell." The new cheap imports from Europe, which began to arrive in Indonesia during the late eighteenth and early nineteenth century, could be gilded with material from Siam or China, while cotton could be embellished with false gold thread and decorated with glass. Above all, the aim was to satisfy a local taste which liked dressing in colors "as lively and glittering as possible." In the interior, where imported silk was less easy to obtain, small quantities were produced locally and mixed with cotton. A traveler in Pasemah in 1817 recorded that worms were being bred for the weaving of scarves, and a manual from the same area, apparently dating from the turn of the eighteenth century, provides simple instructions on how to produce silk. ${ }^{77}$

It also appears that, with the prestige of the Palembang court, locally produced cloth began to acquire a status of its own. In India the textile industry was dying under pressure from cheaper English manufactures, and as middle-class Indian women showed an

\footnotetext{
76B.M. Goslings, "Heeft er te Palembang een door de Eigen Bevolking uitgeoefende Battikkunst Bestaan?" Nederlandsche-Indië, Oud en Nieuw 17, 2 (1932): 53; R.H.M. Akib, Buku Pertama tentang Rumah Adat Limas (Palembang: n.p., 1975), p. 49. Sultan Mahmud's wives are listed in a typescript kindly lent to me by Radin Husin of Palembang.

77Praetorius, "Eenige Bijzonderheden," p. 397; H. 558 Koninklijk Instituut, N.L. Koops, "Aanteekeningen over de Oost Indien. De Rijken Palembang en Riouw," 1836-7, fol. 26; E. Presgrave, "Journey to Pasummah Lebar and Gunung Dempo in the interior of Sumatra," Journal of the Indian Archipelago and Eastern Asia, New Series 2 (1857): 41; Cod.Or. 7653a, fol. 14.
} 
increasing preference for Chinese silk. But in Palembang high-quality local cloth gradually came to be seen as superior to imports and indeed an appropriate gift at life crisis ceremonies. Resident Praetorius, for instance, remarked in 1832 that in the interior a locally made kain tapis, which he compared to a selendang interwoven and embroidered with gold thread and glass, was frequently given as part of the ritual exchange at weddings. The continuing need to produce a variety of woven cloth for all income levels continued even after the sultanate was brought to an end in 1824. According to Praetorius, "almost all women, the noble as well as middle rank, can weave or spin, and the first trade in silk cloth which they do not need for their own use." 78 A cloth which, in the words of a Minangkabau chant, "was woven by someone from Palembang" had become a prized item. In 1800 one visitor noted "scarves" of Palembang silk were being sold right up to the Kerinci border. ${ }^{79}$ Furthermore, these textiles also assumed a value outside the South Sumatra region. Statistics compiled by the Dutch in 1822 show that in that year twenty "silk cloths" were exported to be sold in Java. A decade afterwards, 78 women earned a living by weaving silk and gold thread, supported by hundreds of others who spun, wove cotton, embroidered, batikked, and dyed cloth and so provided an economic base which ensured that at least some textile skills would survive into the twentieth century. ${ }^{80}$

This study of developments in the cloth trade in Palembang and Jambi has been an exercise in regional history. At the beginning of the seventeenth century the Jambi and Palembang courts, so closely linked by blood, also shared many of the same historical experiences. Both began to depend on the income obtained from the expansion of pepper growing in the interior, and both became increasingly involved with the Dutch East India Company. In both places the cultural and economic role of cloth made the textile trade a prime conduit for the purchase of pepper, but Europeans found local tastes become more demanding as new cloth types grew familiar. The ruling elite, in particular, insisted on regular supplies of luxury Indian cloth, especially silk worked through with gold and silver. These preferences caused difficulties in the late seventeenth century when falling pepper prices coincided with a rise in the cost of Indian fabrics. An increase in imports from Java to some extent filled the gap, but the subdued tones of Javanese textiles did not satisfy the more exotic tastes of court circles. The wealth which came to Palembang through the expansion of tin mining, coupled with royal patronage, led to an expansion of local weaving in silk and gold thread in order to satisfy the upper levels of the market. This did not occur in Jambi because of the collapse of its pepper trade, ongoing internal divisions, and an increasing poverty among the elite. By the end of the eighteenth century, in consequence, the textile traditions of Jambi and Palembang had markedly diverged. Today, while most museum collections contain at least one example of Palembang's distinctive weaving styles it is rare indeed to find a single piece from Jambi. ${ }^{81}$

\footnotetext{
${ }^{78}$ Praetorius, "Eenige Bijzonderheden," p. 395.

${ }^{79}$ Nigel Phillips, Syobang, Sung Narrative Poetry of West Sumatra (Cambridge: Cambridge University Press, 1981), p. 49; Presgrave, "Journey to Pasummah Lebar," p. 41; Marsden, History of Sumatra, p. 306.

${ }^{80}$ Praetorius, "Eenige Bijzonderheden," pp. 395-98. See fn. 72; J. J. van Sevenhoven, "Beschrijving van de Hoofdplaats van Palembang," VBG 9 (1823): 77.

${ }^{81}$ See, for example, the textile collections of major North American museums in Mattiebelle Gittinger, ed., Indonesian Textiles. Irene Emery Roundtable on Museum Textiles, 1979 Proceedings (Washington, D.C.: The Textile Museum, 1979), pp. 377-440.
} 


\section{Glossary of Cloth Terms ${ }^{82}$}

(Note: the description and classification of Indian cloth raises major problems because terminology is not consistent. The following is intended purely as a guide to reading.)
alegia Striped, usually blue/white or red/white, normally silk but often com-
- bined with cotton or all cotton. Decorative stripes of gold and silver were also popular

armosin A silk fabric which could be plain, striped, or checked and was often embroidered or brocaded with colored silks or gold and silver thread

bafta Cotton, usually black or white

cambayer Closely woven cotton fabric (?)

canting

chavoni

Small brass pot used in batik work

garra

Light white cotton embroidered with colored silk

gobar

A rough unpatterned calico from Bengal

Brownish blue cloth of cotton with a whitish blue stripe across the middle

kain gulung Exported in rolls, apparently patterned, usually incorporating gold thread

kumitar An expensive batikked cotton

"leijleij" A type of Indian cloth, style not known; "sebagai leileij" thus means a piece of leijleij

"leusols" A type of Indian cloth, style not known

patola Fine double ikat silk, for which Gujarat was famous

salampuri Ordinary calico, usually white with a red stripe at each end, a specialty of Coromandel

tapih A general name for colored piece goods used as skirts by both sexes in many parts of Southeast Asia

tapih Java Distinguished from Malay tapih by smaller flowers and more subdued colors

tapih serasah Multicolored cotton skirt lengths, usually patterned with flowers

tulupakan Cotton skirt lengths, red or black; could be striped or decorated with circles

\footnotetext{
82 Sources: Raychaudhuri, Jan Company in Coromandel, pp. 221-22; G. P. Rouffaer and H. H. Juynboll, De Batik-Kunst in Nederlandsch-Indië en haar Geschiedenis (Utrecht: Oosthoek, 1914), Bijlage III. I am also grateful to Ms. Ruurdje Laarhoven for advice on some types.
} 